Jurnal Biologi dan Pembelajarannya, Vol 6 No 2, Oktober 2019. Pp: 22-25

e-ISSN: $2406-8659$

\title{
KUPU-KUPU DI TAMAN KOTA KEDIRI MEMORIAL PARK
}

\author{
Tutut Indah Sulistiyowati ${ }^{1}$, Mumun Nurmilawati ${ }^{1}$, dan Rizky Hidayatul Wijasari ${ }^{2}$ \\ ${ }^{1}$ Program Studi pendidikan Biologi, Universitas Nusantara PGRI Kediri \\ ${ }^{2}$ SMP ISLAM YBWPI KEDIRI \\ Email: tututindah.team@gmail.com
}

\begin{abstract}
Abstrak
Kupu-kupu merupakan serangga yang bergantung terhadap daya dukung habitatnya. Penelitian ini bertujuan untuk mengetahui keanekaragaman, kemerataan dan kemelimpahan kupu-kupu di Kediri Memorial Park beserta faktor lingkungan yang mempengaruhinya. Metode sampling yang digunakan pada penelitian ini adalah VES (Visual Eccounting Survey). Berdasarkan hasil penelitian ditemukan 6 spesies kupu-kupu. Indeks keanekaragaman sebesar 1,68401 dan indeks kemerataan menunjukkan nilai 0,40646. Derajad kemelimpahan spesies masuk dalam kategori langka, dengan rata-rata perjumpaan kurang dari 5 perjumpaan per hari.

Kata kunci- Kupu-kupu, keanekaragaman, kemelimpahan, faktor lingkungan
\end{abstract}

\section{PENDAHULUAN}

Undang-Undang Nomor 26 Tahun 2007 menyatakan bahwa penataaan ruang wilayah perkotaan harus memuat penyediaan dan pemanfaatan Ruang Terbuka Hijau (RTH) minimal $30 \%$ dari luas wilayah. Ruang terbuka hijau memiliki fungsi utama sebagai paru-paru kota. Kota Kediri memiliki enam RTH, salah satunya adalah Taman Kota Kediri Memorial Park yang berada di Jalan Pahlawan Kusuma Bangsa. Taman Kota Kediri Memorial Park berfungsi sebagai paru-paru kota dan tempat rekreasi masyarakat setempat. Selain itu juga merupakan habitat bagi tumbuhan dan hewan yang ada didalamnya, salah satunya sebagai habitat kupu-kupu.

Kupu-kupu adalah serangga yang termasuk kedalam ordo Lepidoptera. Keberadaan kupu-kupu bergantung pada lingkungannya. Keberadaan kupu-kupu sangat tergantung kepada daya dukung habitat yang memiliki komponen Hostplant dan Foodplant [1]. Apabila salah satu atau bahkan kedua komponen itu tersebut tidak ada, maka kupu-kupu jelas tidak bisa melangsungkan kehidupannya.

Kupu-kupu adalah bagian dari kekayaan hayati yang harus dijaga kelestariannya. Kupu-kupu memiliki peran penting di berbagai bidang, antara lain di bidang ekologi (sebagai pollinator), estetika (sebagai insektarium) maupun ekonomi (sebagai bahan baku serat sutra). Keanekaragaman kupu-kupu menjadi salah satu indikator terjadinya perubahan lingkungan karena kupu-kupu dapat dijadikan indikator lingkungan yang menunjukan keadaan lingkungan biotik dan abiotic [2][3].

\section{METODE PENELITIAN}

Penelitian ini dilakukan di Taman Kota Kediri Memorial Park pada bulan Maret hingga Mei 2018. Metode sampling yang digunakan adalah VES (Visual Eccounting Survey). Parameter kupu-kupu yang diamati adalah jenis kupu-kupu, kemudian dilakukan penghitungan indeks keanekaragaman, kemerataan dan kelimpahan kupu-kupu.

Alat-alat yang digunakan pada penelitian ini antara lain jaring serangga, amplop/kertas papilot, kamera, papan perentang, alat suntik, kertas label, jarum serangga, jam tangan, termohigrometer, alat tulis dan buku panduan identifikasi kupu-kupu. Bahan yang digunakan dalam penelitian ini adalah kupu-kupu yang tertangkap di lokasi penelitian, alkohol 70\% dan kapur barus.

Pengambilan sampel dilakukan setiap hari pukul 06.00 - 17.00 WIB. Identifikasi sampel kupu-kupu menggunakan berbagai buku panduan [4][5][6]. Analisis data dilakukan dengan mengukur indeks keanekaragaman jenis kupu-kupu menggunakan rumus indeks keanekaragaman Shannon-Wiener [7]:

$$
\left(H^{\prime}\right)=-\Sigma p i \ln p i ; \quad p i=n i / N
$$

keterangan:

pi $=$ Proporsi jenis ke-i

$\mathrm{ni}=$ Jumlah individu ke-i

$\mathrm{N}=$ Jumlah individu seluruh jenis 
Jurnal Biologi dan Pembelajarannya, Vol 6 No 2, Oktober 2019. Pp: 22-25

e-ISSN: $2406-8659$

Indeks kemerataan jenis (Evenness) digunakan untuk mengetahui gejala dominansi diantara spesies kupu-kupu, dengan rumus:

$E=\frac{H^{\prime}}{\ln S}$

keterangan:

$\mathrm{E}=$ Indeks kemerataan jenis $(0-1)$

$\mathrm{H}^{\prime}=$ Indeks Shannon

$\mathrm{S}=$ Jumlah jenis

Derajad kemelimpahan relatif kupu-kupu yang dijumpai dalam penelitian dikategorikan dalam empat kelompok (Buden, 2000), yaitu :

1. banyak dijumpai jika minimal tercatat 30 perjumpaan /hari,

2. cukup banyak jika dijumpai 10-30 perjumpaan/hari,

3. sulit jika hanya 5 perjumpaan/ hari dan dikatakan

4. langka jika perjumpaan dibawah 5 perjumpaan/hari.

\section{HASIL DAN PEMBAHASAN}

Penelitian pada Taman Kota Kediri Memorial Park ditemukan enam spesies kupu-kupu dari tiga famili dengan jumlah individu sebanyak 63 individu (tabel 1). Ketiga famili tersebut antara lain Papilionidae, Nymphalidae dan Pieridae. Kondisi lingkungan yang tercatat pada waktu pengamatan menunjukkan suhu $25 \pm 1$ 으 dan kelembaban $78 \pm 2 \%$.

Famili Papilionidae memiliki warna yang menarik merah, kuning, hijau, dengan kombinasi hitam dan putih. Kupu-kupu ini berukuran sedang hingga besar ada jenis-jenis yang mempunyai ekor yang merupakan perpanjangan sudut sayap belakang. Keindahan dan ukurannya yang besar membuat kupu-kupu dari suku Papilionidae ini banyak dicari dan dikoleksi. Menurut Peggie (2014) pengambilan kupu-kupu di alam secara berlebihan dapat menyebabkan kelangkaan dan kepunahan, sehingga sebagian anggota suku Papilionidae termasuk dalam daftar satwa yang dilindungi. Pada penelitian ini ditemukan dua spesies yaitu Graphium agamemnon dan Graphium doson.

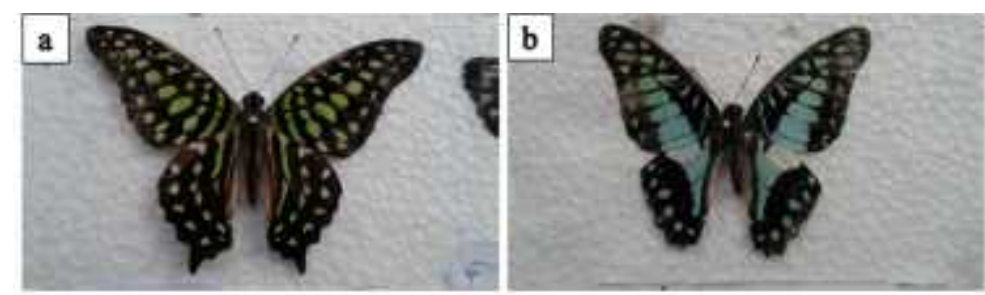

Gambar 1. Famili Papilionidae (a) Graphium agamemnon dan (b) Graphium doson

Famili Nymphalidae merupakan kelompok yang paling beragam jenisnya dengan variasi pola dan bentuk sayap. Menurut Peggie (2014), kupu-kupu famili ini umumnya berwarna coklat, oranye, kuning dan hitam. Kupu-kupu ini memiliki ukuran beragam, mulai kecil sampai besar. Pada penelitian ini hanya ditemukan satu spesies yaitu Hypolimnas bolina.

\section{Gambar 2. Hypolimnas bolina}

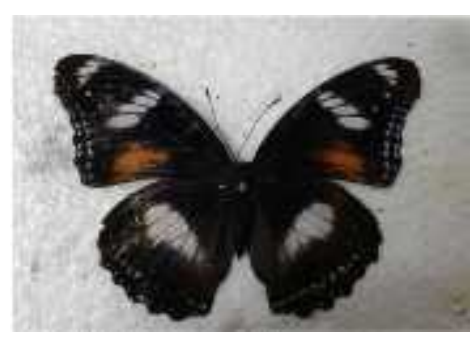

Famili Pieridae berwarna kuning dan putih, ada juga yang berwarna oranye dengan sedikit hitam atau merah. Kupu-kupu ini berukuran kecil sampai sedang. Tidak ada perpanjangan sayap menyerupai ekor. Kupukupu ini mempunyai tiga pasang tungkai untuk berjalan. Menurut Shalihah, dkk (2012) jenis pieridae biasanya menarik perhatian karena terbang berkelompok dan berjumlah banyak. Pada penelitian ini ditemukan tiga spesies yaitu Appias olferna, Eurema blanda dan Leptosia nina. 
Jurnal Biologi dan Pembelajarannya, Vol 6 No 2, Oktober 2019. Pp: 22-25

e-ISSN: $2406-8659$

Gambar 3. Famili Pieridae (a) Appias olferna dan (b) Eurema blanda

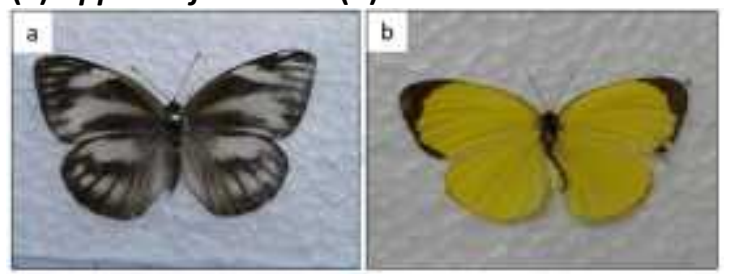

Indeks keanekaragaman, kemerataan dan derajad kemelimpahan kupu-kupu pada penelitian ini ditunjukkan oleh tabel berikut:

Tabel 1. Hasil penelitian di Taman Kota Kediri Memorial Park

\begin{tabular}{lllll}
\hline Famili & \multicolumn{1}{c}{ Spesies } & Jumlah & $\begin{array}{l}\text { Rata-rata } \\
\text { Perjumpaan }\end{array}$ & $\begin{array}{l}\text { *Derajat } \\
\text { Kemelimpahan }\end{array}$ \\
\hline Papilionidae & Graphium doson & 2 & 0.25 & La \\
\hline Nymphalidae & Hypolimnas bolina & 15 & 1.875 & La \\
\hline Pieridae & Appias olferna & 11 & 1.375 & La \\
\hline & Eurema blanda & 14 & 1.75 & La \\
\hline Jumlah Individu & Leptosia nina & 9 & 1.125 & La \\
\hline Indeks Keanekaragaman & 63 & & La \\
\hline Indeks Kemerataan & 1.68401 & & \\
\hline
\end{tabular}

*Derajat kemelimpahan: $\mathbf{B a}=$ banyak, jika minimal tercatat 30 perjumpaan/hari, $\mathbf{C u}=$ cukup banyak, jika 10-30 perjumpaan/hari, Ja = jarang, jika 5-9 perjumpaan/harridan La = langka jika dibawah 5 perjumpaa/hari.

Indeks keanekaragaman kupu-kupu di Taman Kota Kediri Memorial Park termasuk kedalam kategori sedang, hal ini ditunjukkan dengan nilai indeks keanekaragamannya sebesar 1,68401.Indeks kemerataan kupu-kupu pada Kediri Memorial Park menunjukkan nilai sebesar 0,40646, kemeratan kupu-kupu pada Taman Kota Kediri Memorial Park termasuk dalam kategori sedang yang berarti persebaran spesies kupu-kupu pada taman tersebut tidak di dominasi oleh salah satu spesies.

Derajat kemelimpahan seluruh spesies pada Taman Kota Kediri Memorial Park masuk dalam kategori langka, ini ditujukkan dengan rata-rata perjumpaan spesies kurang dari 5 perjumpaan per hari. Kelimpahan kupu-kupu yang sangat rendah ini dipengaruhi oleh berbagai faktor, salah satunya adalah luas kawasan tersebut. Area taman yang tidak terlalu luas membuat populasi kupu-kupu yang dijumpai sangat sedikit. Hal ini didukung oleh Dewi, dkk (2016) yang menyatakan bahwa luas suatu kawasan menentukan kelimpahan individu, semakin luas suatu kawasan maka jumlah individu akan semakin tinggi karena tersedianya banyak tempat untuk bernaung.

Spesies yang ditemukan pada Kediri Memorial Park tidak termasuk dalam spesies yang dilindungi. Namun, spesies-spesies tersebut dikatakan langka berdasarkan rata-rata perjumpaan yang menunjukkan spesies tersebut sulit dijumpai. Banyak faktor lingkungan yang menyebabkan sulitnya kupu-kupu dijumpai pada Taman Kota Kediri Memorial Park. Lokasi taman yang berada dipinggir jalan raya menyebabkan kebisingan dan polusi udara yang berasal dari kendaaraan menyebabkan kupu-kupu terganggu. Pemasangan paving blokdi area taman membuat berkurangnya penunjang kelangsungan hidup kupu-kupu. Putri (2016) menyatakan bahwa pembangunan sarana dan prasarana penunjang wisata seperti pemasangan paving blok, penyemenan dan pembuatan kolam dari tegel keramik menyebabkan berkurangnya areal berpasir yang disukai kupu-kupu untuk hinggap dan menyerap mineral. Selain itu, banyak restoran di sekitar taman yang menimbulkan bau masakan juga membuat kupu-kupu tidak nyaman. Menurut Lamatoa, dkk., (2013) dan Putri (2016) faktor-faktor tersebut menyebabkan kupu-kupu merasa terganggu dan tidak nyaman dengan habitatnya, sehingga membuat kupu-kupu tidak mendatangi areal tersebut dan mencari habitat yang baru. 
Jurnal Biologi dan Pembelajarannya, Vol 6 No 2, Oktober 2019. Pp: 22-25

e-ISSN: $2406-8659$

\section{SIMPULAN}

Berdasarkan penelitian yang dilakukan, ditemukan enam spesies kupu-kupu antara lain Graphium agamemnon, Graphium doson, Hypolimnas bolina, Appias olferna, Eurema blanda dan Leptosia nina. Indeks keanekaragaman kupu-kupu di Taman Kota Kediri Memorial Park sebesar 1,68401 dan indeks kemerataan kupu-kupu pada Kediri Memorial Park menunjukkan nilai sebesar 0,40646. Derajat kemelimpahan seluruh spesies pada Taman Kota Kediri Memorial Park masuk dalam kategori langka, ini ditujukkan dengan rata-rata perjumpaan spesies kurang dari 5 perjumpaan per hari. Beberapa faktor lingkungan mempengaruhi keanekaragaman dan kelimpahan kupu-kupu antara lain luas area taman, pemasangan paving blok, gangguan suara dan asap kendaraan, serta bau masakan dari penjual makanan disekitar taman.

\section{SARAN}

Keberadaan kupu-kupu pada suatu area ditentukan oleh habitat dan sumber pakan. Oleh sebab itu, kelestarian kupu dapat terjaga dengan menjaga tumbuhan habitat dan sumber pakannya.

\section{UCAPAN TERIMA KASIH}

Penelitian ini didanai oleh DRPM Dikti melalui program PDP

\section{DAFTAR PUSTAKA}

[1] Shalihah, A., Pamula, G.,Cindy, R., Rizkawati, W., Anwar, Z.I. 2012. Kupu-Kupu Di Kampus Universitas Padjajaran Jatinangor. Sumedang : Departemen Keilmuan Devisi Entomologi Unpad.

[2] Amin, Nurdin dan Alfida. 2016. Kupu-Kupu (Rhopalocera) Di Kawasan Hutan Kota Bni Banda Aceh. Jurnal Biotik, 4 (2) : 117-127.

[3] Putri. A.S.L.P.I. 2016. Pengaruh Aktivitas Pariwisata Terhadar Keragaman dan Populasi Kupu-Kupu di Taman Nasional Bantimurung Bulusaraung. Jurnal Penelitian Hutan Dan Konservasi Alam, 13 (2): 101-118.

[4] Borror DJ. Triplehorn C.A \& Johnson NF. 1996. Pengenalan Pelajaran Serangga Edisi Keenam. Partosoedjono S, penerjemah; Brotowidjoyo MD, editor. Yogyakarta: Gadjah Mada University Press. Terjemahan dari: An Introduction to The Study of Insects

[5] Peggie, Djunijanti. 2014. Mengenal Kupu-Kupu. Jakarta: Pandu Aksara Publishing.

[6] Dewi, B., Hamidah, A. \& Siburian, J. 2016. Keanekaragaman dan Kelimpahan Jenis Kupu-kupu (Lepidoptera; Rhopalocera) di Sekitar Kampus Pinang Masak Universitas Jambi. Biospecies, 9 (2): $32-38$

[7] Odum, E.P. 1973. Dasar-Dasar Ekologi. Terjemahan Tjahjono Samingan. 1993. Yogyakarta : Gadjah Mada University Press.

[8] Buden, D.W. 2000 The Reptiles of Pohnpei. Feredated Stated of Micronesia. Micronesia, 32 (2): $155-180$.

[9] Lamatoa, C.D., Koneri, R., Siahaan, R., \& Maabuat, V.P. 2013. Populasi Kupu-Kupu (Lepidoptera) di Pulau Mantehage, Sulawesi Utara. Jurnal IImiah Sains, 13 (1): 52-56.

[10] Putri, Ririn Eka dan Dian Mutiara. 2014. Keanekaragaman Kupu-Kupu di Kecamatan Sukarame Kota Palembang Provinsi Sumatera Selatan. Jurnal Sainmatika, 11 (2) : 38-41. 